NBER WORKING PAPER SERIES

\title{
THE GREAT EXCHANGE RATE DEBATE AFTER ARGENTINA
}

\author{
Sebastian Edwards
}

Working Paper 9257

http://www.nber.org/papers/w9257

\author{
NATIONAL BUREAU OF ECONOMIC RESEARCH \\ 1050 Massachusetts Avenue \\ Cambridge, MA 02138 \\ October 2002
}

This is a revised version of the Keynote Speech I delivered at the conference "Monetary Union: Theory, EMU Experience and Prospects for Latin America" organized by the University of Vienna, the Central Bank of Austria and the Central Bank of Chile, held in Vienna, May 2002. Some of the ideas presented here draw from my previous work on exchange rates and financial crises. I thank Edi Hochreiter and Klaus SchmidtHebbel for encouragement, and my co-author Igal Magendzo for stimulating discussions. As always I am grateful to Ed Leamer for his willingness to listen and for his comments. The views expressed herein are those of the author and not necessarily those of the National Bureau of Economic Research.

(C) 2002 by Sebastian Edwards. All rights reserved. Short sections of text, not to exceed two paragraphs, may be quoted without explicit permission provided that full credit, including $(\mathrm{C}$ notice, is given to the source. 
The Great Exchange Rate Debate After Argentina

Sebastian Edwards

NBER Working Paper No. 9257

October 2002

JEL No. F3, F4

\section{$\underline{\text { ABSTRACT }}$}

In this paper I discuss in what way, if any, the collapse of Argentina's experience with a currency board has affected the policy debate on the appropriate exchange rate regime in emerging and transition countries. More specifically, I deal with three issues: (1) I discuss some important aspects of the Argentine experience. (2) I provide a comparative evaluation of economic performance under strict dollarization. And (3), I analyze emerging countries' experiences with flexible exchange rates, including the issue of "fear of floating."

\section{Sebastian Edwards}

UCLA

Anderson Graduate School of Business

110 Westwood Plaza, Suite C508

Box 951481

Los Angeles, CA 90095

and NBER

sebastian.edwards@anderson.ucla.edu 


\section{Introduction}

Not very long ago hybrid exchange rate regimes -- including crawling pegs, crawling bands, and pegged-but-adjustable systems -- were very popular among policy makers and economists in the emerging countries. All of this changed in the late-1990s when as a result of successive currency crises a number of authors began to argue that in a world of high capital mobility, middle-of-the-road exchange rate regimes were highly unstable. As a result of this, during the last few years the so-called "two corners" solution on exchange rate regimes has become increasingly dominant. According to this view countries should either have a floating exchange rate, or they should opt for a superfixed exchange rate regime - that is, a currency board or full official dollarization (Fischer 2001).

During most of the 1990s Argentina, with its currency board, was the poster child of super-fixed regimes. Not only had Argentina done quite well during 1991-97, but more importantly, it was the only large country with a functioning super-fixed exchange rate system. Mussa (2002) explains how, and in spite of initial IMF skepticism, the Argentine experience became increasingly popular in Washington policy circles. The official sector support for the experience is perhaps best captured by the views of Ricardo Hausmann, the influential former Chief Economist of the Interamerican Development Bank, who in April 2001 went as far as arguing that other Latin American countries - including Brazil and Mexico - would soon follow Argentina and adopt a currency board. ${ }^{1}$ Nothing of that sort happened, and in early 2002 Argentina's adventure with a currency board came to an end, when deposits were frozen, the peso was devalued, and the government defaulted on its debt.

The purpose of this paper is to discuss in what way, if any, the collapse of Argentina's experience with a currency board has affected the policy debate on the appropriate exchange rate regime in emerging and transition countries. The rest of the paper is organized in four parts: In Section II I discuss some important aspects of the Argentine experience. In particular, I deal with the run on deposits, and some of the consequences of abandoning convertibility in early 2002. In Section III I discuss how the collapse of Argentina's currency board has affected the arguments in favor of hard pegs.

1 See La Nación, April 6, 2001. 
I point out that most supporters of super-fixed exchange rate regimes have not changed their minds, and continue to believe that hard pegs are an appropriate solution for many problems in the emerging countries. In this section I also provide a summary of the existing evidence on performance under dollarization. Section IV is devoted to discussing emerging countries' experiences with flexible exchange rates, including the issue of "fear of floating." I argue that incorporating exchange rate considerations into a Taylor rule does not constitute "fear of floating." Under most circumstances it is optimal floatation. I also point out that additional research is needed to understand whether "sterilized" intervention in foreign exchange markets is destabilizing. Finally, Section VI I present some concluding thoughts, including some remarks on the practical relevance of the "two corners" approach to exchange rate policy.

\section{Argentina's Crisis, De-dollarization and Money Overhang}

Throughout its currency board experience, Argentina had a highly dollarized economy. The public was repeatedly told that "a peso is a dollar, and a dollar is a peso," and was encouraged to hold dollar-denominated deposits. A high percentage of banks' portfolios were dollar-denominated, and by late 2001 more than 80 percent of the public debt was denominated in foreign currency. Because of this high degree of dollarization, even authors that had questioned the wisdom of the hard peg and had argued that the peso was overvalued, were skeptical about the benefits of a devaluation of the peso. In the presence of a high degree of balance sheet dollarization, they argued, a (real) devaluation would result in a large increase in debt burdens, and would unleash a string of bankruptcies.

Towards mid 2001, and in the mist of a four-year recession, the Minister of the Economy Domingo Cavallo was desperately trying to deal with a perverse debtdynamics. With the country risk premium exceeding 2,000 basis points, and with an increasingly contentious disagreement with the provinces regarding revenue transfers, Cavallo was rapidly running out of time. As economic conditions deteriorated, a growing number of analysts began to debate publicly alternative ways out of the convertibility law. On one camp were those that favored a partial default, while maintaining the basic features of convertibility and the currency board; on another camp were those that argued 
that the only way out was to officially dollarized the economy, possibly at a rate higher that the prevailing one peso per dollar. Another group called for a devaluation-cumpesification, followed by the adoption of a generalized indexation scheme. ${ }^{2}$

As it turned out, Minister Cavallo dismissed all of these schemes and insisted on his own program based on restructuring the public debt, providing an array of incentives to the industrial sector, and negotiating with the provinces. In early December 2001, and as a way to quell a rapidly growing run on the banking system, the government implemented a deposit freeze and de facto exchange controls. The public, which had repeatedly been assured that their savings were untouchable, was stunned. It soon took to the streets and staged violent demonstrations that were severely repressed by police forces. By December 19, and after more than twenty people were killed during violent protests, the government appeared to have lost control over events. A day later President de la Rua resigned, bringing an era to an end. In rapid succession Argentina went through three short-lived chief executives, until in mid-January 2002 Eduardo Duhalde a Senator and former governor of the province of Buenos Aires - was appointed President by congress, with the mandate of finishing Mr. De la Rua's period. ${ }^{3}$

The new authorities were quick to denounce the "old" economic policy including the convertibility law -- as inefficient, recessionary and corrupt. In designing a new policy, however, they did not follow any of the blueprints that had been thoroughly discussed in the preceding months. Instead, they implemented a series of measures that included the worst elements of each of the existing proposals. The peso was devalued, public debt - or most of it -- was defaulted, and dollar-denominated private debts were “pesified” at different and arbitrary rates. Moreover, Cavallo's deposit freeze was generalized and strengthened, and the public was forbidden to transfer deposits across banks. The peso, which for more than a decade had stood at parity with the U.S. dollar, rapidly lost value, and in a few weeks the exchange rate surpassed the 3 pesos per dollar mark. Politicians and many local analysts were astounded. Not in their worst nightmares

\footnotetext{
${ }^{2}$ Default, or partial default, was supported by a number of U.S. economists, including Charles Calomiris, Allan Meltzer, and Adam Lerrick. This view was also supported by a number of Argentine politicians both from the opposition as well as from the main government party. Dollarization was supported by a group of American academics, by the financial page of the Wall Street Journal, by former president Carlos Menem and by a group of Peronist economists. Pesification followed by indexation and a floating exchange rate was supported by the editorial page of the Financial Times and by former IDB Chief Economist Hausmann.
} 
did they expect the nominal devaluation to exceed 60 percent. ${ }^{4}$ Growth forecasts for 2002 indicate that GDP will contract between 15 and 20 percent; for 2003 most analysts expect and additional drop in GDP of the order of 5 percent.

These tragic events showed that in a de-facto dollarized economy a devaluation can be very messy indeed. Bank and corporate balance sheets were wrecked, and depositors clamored to get their money back. Populist promises by the government did not help, and months after the currency was devalued the country was still paralyzed. Political instability grew by the day, as the population staged demonstrations against politicians, judges and bankers. It became rapidly evident that reestablishing the payments system was a fundamental requirement for getting the economy moving again. This, however, required finding a solution for the deposit freeze problem; as long as deposits were frozen, there was little chance of getting banks functioning in a quasinormal way.

The events of December 2001-January 2002 generated a colossal collapse in the demand for money in Argentina. People that for over a decade had been told that a peso was as good as a dollar, suddenly realized that this was not the case. Not only a peso was not a dollar, but also after the freeze a "peso" was not even a "peso." Simply put, people did not want to hold the Argentine currency. Yet, because deposits were frozen, they were unable to dispose of unwanted pesos. By early 2002 Argentina faced a massive monetary overhang situation, similar to that prevailing in the Eastern European countries during the late $1980 \mathrm{~s}$ and early $1990 \mathrm{~s}^{5}$

The economic theory of monetary overhangs is well known and simple, and goes back at least to David Hume. Under fixed exchange rates the undesired domestic money leaves the economy through a reduction in international reserves. This is, indeed, the main insight emphasized by the monetary approach to the balance of payments. This option, of course, was not available to Argentina, as the country had virtually run out of foreign exchange reserves. Under flexible exchange rates a monetary overhang is resolved through jumps in the nominal exchange rate and in the price level. These nominal adjustments have to be large enough as to eliminate the difference between the

3 At the time of this writing, however, elections had been moved forward to March, 2002.

4 Most computations of the extent of overvaluation were in the range of 30-45 percent.

5 See Lipton and Sachs (1990) and Edwards (1992). 
desired and actual stocks of (real) money. ${ }^{6}$ While in theory, these could be once-and-forall jumps, in reality this type of adjustment tends to generate all sorts of macroeconomic pressures, and usually unleashes an inflationary process that is difficult to control. It is indeed for this reason that throughout the first half of 2002 the IMF argued that lifting the deposit freeze would generate chaos. As an alternative they proposed substituting long term bonds for frozen deposits - the characteristics of these bonds, and in particularly whether the exchange was to be voluntary and mandatory became a source of heated debate. Expropriation of deposits has had a recurrent history in Argentina - the most recent episode took place in 1989, when the so-called Bonex Plan was put into place.

An important question refers to the initial magnitude of the monetary disequilibrium generated by the deposit freeze, the devaluation of the peso and default on the public sector debt. ${ }^{7}$ This disequilibrium - and the associated pressure over the price level and the nominal exchange rate -- depend on four key factors: (1) The extent of the decline in the demand for money. (2) The exchange rate at which dollar-denominated deposits are "pesified." (3) Whether "pesified" deposits are subsequently indexed; and if so, in what manner. And (4) whether all frozen deposits are freed up. It is easy to show that the post-crisis (and pesification) equilibrium price level $\left(\mathrm{P}_{1}\right)$ and exchange rate $\left(\mathrm{E}_{1}\right)$ - defined as the ones that fully clear the money overhang in the absence of a freeze -- are equal to:

$$
\begin{aligned}
& \mathrm{P}_{1}=\left(\mathrm{C}_{0}+\mathrm{D}_{0}+\mathrm{F}_{0} \mathrm{E}_{\mathrm{P}}\right) /\left(\mathrm{m}_{1} \mathrm{y}_{1}\right) . \\
& \mathrm{E}_{1}=1+\left[\left(\mathrm{P}_{1}-1\right) /(\mathrm{b} \mathrm{a}+\{1-\mathrm{b}\})\right] .
\end{aligned}
$$

Where it is assumed that prior to the crisis $\mathrm{P}_{0}=\mathrm{E}_{0}=1 . \mathrm{C}_{0}$ is the stock of currency (in pesos) in circulation before the crisis, $\mathrm{D}_{0}$ is the stock of peso denominated deposits both checking account and time deposits -- before the crisis, $\mathrm{F}_{0}$ is the pre-crisis stock of dollar-denominated deposits in the banking system, $\mathrm{E}_{\mathrm{P}}$ is the exchange rate at which

\footnotetext{
6 In theory, increasing the demand for money is an alternative way of solving the disequilibrium. This, however, is not likely to happen in Argentina any time soon.
} 
these deposits are transformed into pesos after the crisis, and $m_{1}$ is the new (post crisis) desired holdings of money relative to nominal GDP. That is, $\mathrm{m}_{1}=\mathrm{M}_{1} /\left(\mathrm{P}_{1} \mathrm{y}_{1}\right)$; for $\mathrm{M}$ denoting the stock of broadly-defined nominal money, and y real GDP. In equation (2), b is the share of non-tradable goods in the price level, and a is the "pass-through" coefficient. $^{8}$

From these equations it is clear that: (a) the new equilibrium price level will depend on the new demand for money $\mathrm{m}_{1}$, and on the rate at which dollar-denominated deposits are "pesified" $\left(\mathrm{E}_{\mathrm{P}}\right)$. The higher is the "pesification" rate, the higher will be the required jumps in $\mathrm{P}$. The lower is the new money demand, the higher will be the required jump in the nominal price level. And (b) the new equilibrium nominal exchange rate will depend on the same variables as $\mathrm{P}_{1}$, as well as on the weight of tradables in the price level, and the "pass-through" coefficient. A higher pass-through, dampens the effect of price increases on the nominal exchange rate, and results in a lower real exchange rate adjustment.

Using data from late 2001 it is possible to estimate the "notional" or equilibrium nominal exchange rate $\left(\mathrm{E}_{1}\right)$, and price level $\left(\mathrm{P}_{1}\right)$ in the post crisis period. Just prior to the crisis, currency in circulation was approximately 11 billion pesos; peso-denominated deposits stood at15 billion pesos; and dollar denominated deposits amounted to approximately US\$45 billion. These deposits were originally pesified at a 1.4 pesos per dollar rate. Assuming a decline in real GDP of 10 percent for 2002 - a figure that according to most analysts is on the optimistic side --, we can use a figure of 250 billion pesos for $y_{1}$. On the bases of a number of studies I assume that the share of tradable goods in the price level is 0.5 , and the pass through coefficient of 0.6 . The final piece of information required for estimating equations (1) and (2) is the post-crisis demand for money. Consider, as an illustration, the case where the new demand for (broad) money is equal to 7 percent of GDP. ${ }^{9}$ In this case $\mathrm{P}_{1}$ would climb from 1 before the crisis, to 5 after the crisis, implying a cumulative rate of inflation of 400 percent. Under these

\footnotetext{
7 In what follows I concentrate on the initial - that is early 2002 - monetary pressures. The changing rules on de-dollarization result in some changes in the magnitudes involved. The final effect, however, is similar to what I report in this section.

8 In deriving equations (1) and (2) I used the following expression for inflation: $\pi=b \pi_{N}+(1-b) \delta$, where $\pi_{\mathrm{N}}$ is nontradables inflation, and $\delta$ is the rate of nominal devaluation. I also used the following "pass-through" equation: $\pi_{\mathrm{N}}=\mathrm{a} \delta$.
} 
assumptions the new equilibrium nominal exchange rate would be 5.1 pesos per dollar. If, however, the new demand for money ratio is as low as 5 percent of GDP, the equilibrium "notional" exchange rate climbs to 8.7 pesos per dollar! Even an optimistic assumption of a post crisis M to GDP ratio of 10 percent still implies a very high new equilibrium nominal exchange rate of 4.2 pesos per dollar. Notice that this analysis has ignored indexation. If, however, "pesified" deposits are indexed to inflation, the pressure on the nominal exchange rate would be even greater, and under some constellation of parameters may even be explosive.

Although the economic profession is still digesting the lessons from Argentina's traumatic crisis, it is already possible to extract some clear conclusions. Most of these lessons are neither new, nor are they surprising. In fact, as the crisis unfolded many observers of the Argentine scene warned the authorities that the experience from prior crises suggested that Argentina was facing a very vulnerable situation. As is usually the case, the authorities sneered at these warnings, arguing that Argentina was really very different from other countries.

It is worthwhile repeating these lessons, as in policy circles there is a frightening tendency to forget history. A partial list of lessons, both old and new, would include the following:

- At the most obvious level the Argentine crisis shows that, contrary to the claims of some of its most ardent supporters, a super-fixed exchange rate regime is not on its own a solution to a country's macroeconomic problems. In simple words, a currency board is not "a panacea."

- The existence of a currency board does not "force" politicians to run a prudent fiscal policy, nor does it result into a lasting low-inflation equilibrium. ${ }^{10}$

- A perverse fiscal dynamics - where the country fails to generate a primary surplus large enough as to stabilize the debt to GDP ratio - usually generates a vicious circle, where failure to stabilize the debt ratio results in higher cost of funds, lower growth, and in an even larger required primary surplus.

\footnotetext{
${ }^{9}$ In mid 2001 the ratio of broad money to GDP stood at approximately 40 percent of GDP.

10 Hanke and Schuler (1994, page 28) arguably two of the most ardent supporters of currency boards wrote: "Because a CB [currency board] cannot finance budget deficits..., the CB establishes an implicit low-inflation fiscal constitution..."
} 
- Fiscal federalism issues are of paramount importance when determining the political economy of fiscal policy. In Argentina, the inability to bring the provinces' finances into check was a key ingredient in the unfolding of the crisis. Institutional arrangements that bring different province or states into line with overall fiscal objectives may help. An important question, however, is how to design exactly such institutions. Some have argued that the EMU's "Growth and Stability Pact," is the type of institution that would help deal with fiscal federalism issues. ${ }^{11}$ Whether the pact actually works in the future is still to be seen, however.

- Situations of real exchange rate overvaluation are very costly, and lead to low growth and in some cases even stagnation. Moreover, under super-fixed nominal exchange rate regimes overvaluation is very difficult to resolve. This notion is far from new - in fact, Keynes wrote extensively about it when discussing inter-war international financial problems --, but is one that policy makers seem to forget over and over again. ${ }^{12}$

- Economies with a low degree of openness to international trade have difficulties adjusting to external shocks. More specifically, and as has been emphasized by a number of authors since at least James Meade's monumental oeuvre The Balance of Payments, the costs of adjustment are proportional to the inverse of the marginal degree of openness of the economy.

- In the presence of de facto dollarization, large devaluations wreck balance sheets, and generate very costly bankruptcies. This, in fact, was also one of the most important lessons of the Chilean currency crisis of 1982.

Surprisingly, not enough attention has been given to that particular episode when studying the genesis of modern currency crises. ${ }^{13}$

- Defaulting on the public may be very costly. Indeed, contrary to what a number of foreign and Argentine analysts had claimed the experience of Argentina during 2002 indicates that there isn't such a thing as a "painless"

11 See Hochreiter, Schmidt-hebbel and Winckler (2002), for a discussion along these lines.

12 Of course, the overvaluation lesson is an important one from previous Latin American crises, including Chile's crisis in the 1970s and the Mexican crisis of 1994. 
default. Some may argue that it was not the default per se what caused so much havoc, but rather the awful policies that accompanied it. But that is exactly the point. Defaults don't come in a clean, surgical way. They are messy and costly.

- Perhaps the most important lesson stemming from Argentina is that, contrary to what a number of authors have claimed, a banking system dominated by major foreign banks may still be subject to a run on deposits. This was indeed what happened in Argentina throughout 2001, and what induced Minister Cavallo to impose the ill-fated deposit freeze and exchange controls in early December of that year. ${ }^{14}$

- Related to the previous point, there are a number of serious risks associated to a highly dollarized banking system. In particular, in the absence of a lender of last resort - as is almost always the case when the banking system is highly dollarized -- a run-of-the-mill crisis may be transformed into a major catastrophe. An important question is whether it is wise for emerging markets to encourage foreign-currency denominated deposits in their banking system.

\section{The Argentine Debacle, the Quest for Hard Pegs, and Dollarization}

Most supporters of super-fixed exchange rate regimes have not changed their views after the Argentine debacle. Instead, they have followed a three-part strategy. The first component of this strategy has been a "bastardization" of the Argentine experience. All of a sudden no one recognizes Argentina as having been an example of a true hard peg regime. The Wall Street Journal editorial page, which for a number of years supported Argentina, suddenly argued that Argentina didn’t really have a "true" currency board, or sound monetary policy. Although it is true that some analysts referred to the Argentine arrangement as "mimicking" a currency board, it is also true that before the

13 Edwards and Edwards (1991).

14 A standard criticism of hard pegs - currency boards and dollarization -- is that the country is left without a lender of last resort. Supporters of super-fixed regimes responded that to the extent that the banking system is dominated by top-of-the-line foreign banks, a run on deposits would be unthinkable. Argentina proved that this is certainly not the case. 
crisis the vast majority of super-fixers praised the Argentine experience. ${ }^{15}$ This "bastardization" strategy may be somewhat effective in debates carried out in the popular press, but is not very interesting from an intellectual point of view, and I will not it any further. The second component of the "super-fixers" post-Argentina strategy is to argue that the preferred super-fixed regime is "dollarization," or a regime where the country in question gives up its own currency and adopts an advanced nation currency as legal tender. According to this argument, countries that dollarize will truly eliminate currency risk, and will outperform nations with a currency of their own. Finally, the third element of the super-fixers' strategy has been to argue that emerging markets have no alternative but to adopt a (true) hard peg (i.e. dollarization). According to this view, emerging countries cannot really adopt a flexible exchange rate: they exhibit "fear of floating," and systematically intervene in the foreign exchange market in a destabilizing way. In this section I will deal with dollarization and its record; in Section IV I focus on the feasibility of flexible exchange rates in emerging countries.

\section{III.1 Dollarized Countries are Very Small}

There is a great myth about dollarization. It turns out that until recently we knew very little about how countries have performed under this regime, and most of what we know is based on the experience of Panama, a country that has been dollarized since 1904. My co-author I.Igal Magendzo and I have looked at this issue quite carefully, and we have been able to find twenty independent countries that have strict dollarization and enough data as to perform a serious evaluation. The starting point in this discussion is to notice that the median population of those 20 independent countries is 145,000 people not exactly large countries. Moreover, these small countries don't collect a lot of data; as a result it is not possible to know much about their economic record. There are certain things, however, that we do know about dollarized economies. For example, we know that they have higher bilateral trade than countries with a currency of their own. This is a result that comes from research undertaken by Engel and Rose (2002) and Frankel and Rose (2002). Persson (2001), however, has persuasively argued that even though this trade effect exists, it is not nearly as strong as it was originally thought. We also have

${ }^{15}$ Kurt Schuler, the author of some of the most serious work on currency boards, even included Argentina in his "team of currency boards," in a public wager that he posted in the Internet. 
some (limited) evidence indicating that although currency risk tends to disappear, dollarized countries don't necessarily have a lower cost of capital than countries with a currency of their own. Consider the case of Panama, the dollarized nation par excellence. Between 1997 and 1998, for example, the average daily spread on Panamanian dollardenominated Brady par bonds was 464 basis points. Although this was lower than the spread on equivalent Argentine bonds ( 710 basis points), it was not the lowest spread in Latin America. In fact, and as is illustrated in Edwards (2001), during this period the spread over Panamanian bonds was systematically and significantly higher than that over Chile's sovereign bonds of similar maturity. ${ }^{16}$ Interestingly, Chile is a country that during the period under discussion experienced an overall increase in its degree of exchange rate flexibility. The comparison between Chile and Panama underscores the very simple but important point that dollarization does not by itself reduce country risk. In fact, during the last few years, and in spite of its improved fiscal performance, Panama has experienced a sizable country risk premium and has been subject to "contagion." 17

\section{III.2 Dollarization and Economic Performance: Some Formal Tests}

In a series of papers Igal Magendzo and I have used a cross-country panel data set to investigate performance - GDP per capita growth, inflation and growth volatility -- in dollarized countries. The data set is an unbalanced panel that covers 1970 through 1998, and includes 199 counties and territories - both dollarized countries and countries with a currency of their own. The number of observations varies, depending on the performance variable considered. There are 3,174 observations on inflation and 4,888 observations on growth per capita. In investigating the behavior of volatility we used a cross section for 1990-97 that includes 194 countries. ${ }^{18}$ The data set includes data on 20 strictly dollarized countries.

We compared performance in dollarized and countries with a currency of their own, using a "treatment effect" methodology. More specifically, we undertook a non-

\footnotetext{
16 Bogetic (2000, p. 193) has claimed that "Panama's sovereign spreads have been consistently lower than in other Latin American countries." As figure 1 shows, this is not so. The spreads in Figure 1 correspond to daily data for Panama's $8 \frac{1 / 2}{\%}$ sovereign bond due in 2008, and Chile's $67 / 8 \%$ sovereign bond due in 2009.

${ }^{17}$ El Salvador, a country that dollarized recently, will eventually provide an interesting case study that will allow us to learn more about the effects of dollarization on interest rate behavior, the cost of capital and other key macroeconomic variables.

18 When alternative 5-year averages were used, there were no significant changes in the results.
} 
parametric analysis based on "matching estimators" (see Blundell and Costa-Dias2000). A general advantage of this non-parametric method is that no particular specification of the underlying model has to be assumed. ${ }^{19}$ Matching estimators pair each dollarized country with countries from the with-domestic-currency group. If the sample is large enough, for each treated (dollarized) observation we can find, in principle, at least one untreated observation with exactly the same characteristics as the treated - in our case dollarized -- observation. Each of these properly selected untreated observations provides the required counterfactual for our comparative analysis. ${ }^{20}$ The problem is that under most general conditions it is not possible to find an exact match between a treated and untreated observation. The matching estimator method focuses on estimating an average version of the parameter of interest. ${ }^{21}$ That is, the matching estimator consists of obtaining the difference in outcome as an average of the differences with respect to "similar" -- rather than identical -- untreated outcomes. Rosenbaum and Rubin (1983) have shown that an efficient and simple way to perform this comparison is to rely on a propensity score, defined as the probability of participation or treatment: $P(x)=\operatorname{Prob}(D=1 / x)$. In our case, this is the probability of a country being a dollarized country. This reduces a multi-dimensional problem to a one-dimensional problem, provided that we can estimate $P(x)$. Instead of matching countries directly on all of their characteristics, we can compare countries with similar probability of being a dollarized country. We used two alternative methods for computing matching estimators. First, we used a simple-average nearest neighbor estimator. According to this method, for each

\footnotetext{
${ }^{19}$ If we estimate the equation above using all non-treated observations the selection bias is given by: $B(x)=E\left(u_{0} / x, D=1\right)-E\left(u_{0} / x, D=0\right)$.

${ }^{20}$ In order to guarantee that all treated agents have such a counterpart in the population (not necessarily in the sample) we also need to assume that $0<\operatorname{Pr} o b(D=1 / x)<1$.

${ }^{21}$ This averaged version is given by:

$M(S)=\frac{\int_{S} E\left(y_{1}-y_{0} / x, D=1\right) d F(x / D=1)}{\int_{S} d F(x / D=1)}$,
}

where $\mathrm{S}$ is a subset of the support of $x$ given $D=1$. 
treated observation, we select a pre-determined number of untreated nearest neighbor(s). The nearest neighbors of a particular treated observation $i$ are defined as those untreated observations that have the smallest difference in propensity score with respect to $i$. If we choose to use $n n$ nearest neighbors, we set $W_{i j}=\frac{1}{n n}$ for the observations that have been selected; for other observations we set $W_{i j}=0$. We applied the above method to both one nearest neighbor and five nearest neighbors. The second method consists of using local linear regressions to identify each matching observation (Fan 1993).

The results from the matching estimators in Edwards and Magendzo (2001) are presented in Table 1. For each variable of interest -inflation, growth, and volatility - the table reports data on (a) the number of countries and number of observations in the control group; (b) The "mean difference," calculated as the mean of the differences, for each variable, of the dollarized economies and the corresponding non-dollarized control group. And (c) the "median difference," calculated as the median of the differences of the dollarized economies and the corresponding non-dollarized control group. For both the mean and the median difference the table includes, in parentheses, a t-statistic for their statistical significance. The test for the mean difference is a standard t-statistic, while that for the difference in median was calculated using a bootstrapping procedure. Finally, and for comparison purposes, I report the means and medians differences obtained when the unadjusted control group of all dollarized countries is used ("unadjusted comparisons").

The results may be summarized as follows: First, for every one of the matching indicators both the mean and median difference in inflation are negative and significantly different from zero. This indicates that the dollarized economies have had significantly lower yearly rate of inflation than the non-dollarized countries. According to these results, however, the mean difference in inflation is much smaller that what the simple, uncorrected comparisons would suggest. Second, for every one of the matching indicators the GDP per capita growth differences - both for means and medians -- are negative. And they are significantly negative in seven out of the eight matching estimators reported in Table 1; the only exception is for the mean difference using one nearest neighbor. Overall I interpret these results as providing fairly strong evidence that, 
once appropriate control groups are defined, the dollarized economies have tended to experience lower GDP per capita growth than the non-dollarized ones. This conclusion is, in fact, supported by the local linear regression results reported in Edwards and Magendzo (2001). In terms of magnitudes, the results from the matching analysis indicate that dollarized countries' underperformed no-dollarized countries by a wider margin than what simple comparisons suggest. The (statistically significant) mean differences in GDP per capita growth in Table 1 range from $-1.56 \%$ per year to $-1.12 \%$ per year; the unadjusted mean difference is only $-0.69 \%$. The median differences in GDP per capita growth in Table 1 range from $-1.53 \%$ per year to $-1.01 \%$ per year; the unadjusted mean difference is $-1.41 \%$. And third, statistically speaking, the matching results reported in Table 1 indicate there are no differences (either in the means or medians) in volatility in dollarized and non-dollarized economies.

\section{On the Feasibility of Exchange Rate Flexibility in Emerging Countries: Fear of Floating or Optimal Floatation?}

For many years it has been argued that emerging countries cannot successfully adopt a freely floating exchange rate regime. This view has recently become particularly popular among supporters of super-fixed exchange rate systems. Two reasons have traditionally been given for this position: first, it has been argued that since emerging countries' tend to export commodities and/or light manufactures, a floating exchange rate would be "excessively" volatile. Second, and related to the previous point, it has been argued that emerging countries don't have the institutional requirements for undertaking effective monetary policy under purely floating exchange rates (Summers 2000). According to this perspective, emerging markets that float would be unable to implement the type of (rather complex) feedback rule required for implementing an effective inflation targeting system. In particular, it has been argued that countries that float after currency crisis will be unable to stabilize the value of their currency. This view is captured expressed in Eichengreen et al (1998 p. 18-19) who after discussing the merits of floating rates and inflation targeting, state: 
"[I]t is questionable whether a freely floating exchange rate and an inflation target objective for monetary policy are feasible, advisable or fully credible for many developing and transition economies...[T] hese economies are subject to substantial larger internal and external shocks... and the transmission mechanisms through which monetary policy affects the economy and the price level tend to be less certain and reliable..."

More recently, a new objection to floating in emerging markets has been raised. Some authors, most notably Calvo (1999), Calvo and Reinhart (2002) and their associates, have argued that in a world with high capital mobility, incomplete information, fads, rumors and a dollar-denominated liabilities the monetary authorities will be severely affected by a "fear to float" (Reinhart 2000). This is because significant exchange rate movements - and in particular large depreciations - will tend to have negative effects on inflation and on foreign currency denominated debt. According to this view, "floating regimes" in emerging markets will be so only in name. In reality, countries that claim to float will be "closet peggers," making every effort, through direct intervention (selling and buying reserves), and interest rate manipulation, to avoid large exchange rate fluctuations. These countries will be in the worst of worlds: they will have a de-facto rigid exchange rates and high interest rates. Reinhart (2000) has aptly summarized the "fear to float" view:

"Countries that say that they allow their exchange rate to float mostly do not; there seems to be an epidemic case of "fear of floating." Relative to more committed floaters...exchange rate volatility is quite low...[T] his low relativeexchange rate volatility is the deliberate result of policy actions to stabilize the exchange rate..." (page 65).

After analyzing the behavior of exchange rate, international reserves and nominal interest rate volatility, Reinhart (2000) concludes that those emerging markets usually considered to be floaters - Bolivia, India and Mexico - are subject to the fear of floating syndrome. She goes on to argue that, under these circumstances, "lack of credibility remains a 
serious problem," and that the only way to avoid it may be "full dollarization." (page 69) - see also Calvo and Reinhart (2002).

In a recent paper Levy and Sturzenegger (2000) follow (independently) an approach similar to that proposed by Reinhart (2000) to analyze exchange rate policy in emerging economies. These authors use data on the volatility of international reserves, the volatility of exchange rates, and the volatility of exchange rate changes for 99 countries, during the period 1990-1998, to determine their "true" exchange rate regime. Their analysis begins with the well-known fact that the classification system used by the IMF tends to misclassify countries. The authors undertake a series of cluster analysis exercises to classify the countries in their sample into five categories: (1) fixed; (2) dirty float/crawling peg; (3) dirty float; (4) float; and (5) inconclusive. The results from this study tend to contradict the "fear of floating" hypothesis. Indeed, Levy and Sturzenegger find out that for their complete sample, 273 cases out of a total of 955 , can be classified as floaters. This, of course, does mean that a number of countries are wrongly classified according to the IMF. For example, they find that in 1998 there were 12 countries that had classified as floaters by the Fund, but that did not really float. Interestingly enough, there were also some fixers that did not fix (see also the recent paper by Reinhart and Rogoff, 2002).

Some of the emerging countries that, according to Levy and Sturzenegger, had a floating regime during 1997-98 (the last two years of their sample) include Chile, Colombia, Ghana, India, and South Africa. A particularly important case is Mexico, a country whose authorities have strongly claimed to have adopted a floating rate after the collapse of 1994. The Levy and Sturzenegger analysis indeed suggests that, after a transitional period in the two years immediately following the currency crisis, Mexico has had, since 1997, a freely floating exchange rate regime. According to this study, during 1995 Mexico had a dirty/crawling peg regime. This evolved, in 1996, to a dirty float, and finally in 1997 to a freely float. This means, then, that Mexico's experience can indeed be used as an illustration of the way in which a floating regime will tend to work in an emerging country. Of course, it is not possible to extract general conclusions from a single episode, but in the absence of other experiences with anything that 
resembles a floating rate, analyses of Mexico's foray with exchange rate flexibility should prove very useful.

\section{IV.I Volatility and External Disturbances}

Detailed studies on (nominal) exchange rate volatility in emerging countries provide no support for either the idea that these have been excessively volatile or "abnormally" stable. An analysis reported by Edwards and Savastano (2000) for the case of Mexico indicate that the peso dollar rate was as volatile as the other currencies during 1997. In 1998, its degree of volatility increased significantly, but was lower than the yen/dollar rate. In 1999 the extent of volatility declined, and the peso was once again in the middle of the pack. The overall conclusion from the high frequency volatility analysis is, then, that there Mexico does not appears to be different, in terms of volatility, from other floaters.

In a recent paper Edwards and Levy-Yeyati (2002) have used the new exchange rate regime classification to investigate whether floating exchange rates act as effective shock absorbers and, thus, help countries deal with external disturbances. They use a panel data set and analyze the way in which terms of trade shocks impact real GDP growth. Their results indicate that countries with (genuine) flexible exchange rates are less affected by terms of trade disturbances, and tend to grow faster than countries with rigid or semi-rigid exchange rare regimes.

\section{IV.2 Monetary Policy, Feedback Rules, Intervention and "Fear of Floating"}

The "fear of floating" critique implicitly assumes that the optimal policy for the emerging countries is a clean float, without any type of government intervention. Thus, by intervening in the foreign exchange market, the authorities are pursuing a sub-optimal course of action and are introducing destabilizing forces. This, however, needs not be the case. Indeed, it is perfectly possible that the optimal policy - that is as the policy that minimizes a well-defined loss function - is one where the central bank intervenes from time to time.

From a technical point of view this discussion may be framed in terms of the form of the Taylor rule in an small open economy. Taylor himself has posed the problem as follows (2001, p. 263): "How should the instruments of monetary policy (the interest rate 
or a monetary aggregate) react to the exchange rate?" In order to address this question more formally, consider the following equation (See Taylor, 2001):

$$
r_{t}=f \pi_{t}+g_{t}+h_{o} e_{t}+h_{1} e_{t-1}
$$

Where $r_{t}$ is the short term interest rate used by the central bank as a policy tool, $\pi_{t}$ is the deviation of the rate of inflation from its target level - possibly zero --, $\mathrm{y}_{\mathrm{t}}$ is the deviation of real GDP from potential real GDP, and $\mathrm{e}_{\mathrm{t}}$ is the log of the real exchange rate in year $\mathrm{t}^{22} \mathrm{f}$ and $\mathrm{g}$ are the traditional Taylor rule coefficients; $\mathrm{h}_{0}$ and $\mathrm{h}_{1}$ are the coefficients of the current and lagged log of the real exchange rates in the expanded Taylor rule, and are the main interest of this discussion. Traditional analyses have assumed that the central bank should ignore open economy considerations when undertaking monetary policy - in terms of equation (3) this means that $\mathrm{h}_{0}=\mathrm{h}_{1}=0$. It is conceivable, however, that in a small open economy the optimal monetary policy rule - that is the policy that maximizes the authorities' objective function - is one where both $\mathrm{h}_{0}$ and $\mathrm{h}_{1}$ are different from zero. Interestingly, if $\mathrm{h}_{0}<0$ and $\mathrm{h}_{1}=-\mathrm{h}_{0}$, then the rule implies that monetary policy should react to changes in the (real) exchange rate. Notice that the formulation in equation (3) does not imply, even when $\mathrm{h}_{0}$ and $\mathrm{h}_{1}$ are different from zero, that the monetary authorities should defend a certain level of the exchange rate.

If the optimal policy calls for intervention - that is for $\mathrm{h}_{0}$ and $\mathrm{h}_{1}$ different than zero --, and if the monetary authorities do follow this policy, a casual observer may conclude that the country in question is subject to "fear of floating." This, however, would be an incorrect inference, as the country in question would be practicing "optimal flotation."

At this point the profession seems to be somewhat divided on whether $\mathrm{h}_{0}$ and $\mathrm{h}_{1}$ should indeed be different from zero. For example, Taylor (2001) has expressed some skepticism on the merits of adding the exchange rate into the interest rate equation; he argues that the exchange rate already plays an indirect role through its effect on $\pi_{\mathrm{t}}$ and $\mathrm{y}$ t. Ball (1999), Obstfeld and Rogoff (1995) and Svensson (2000), and on the other hand, have argued that adding the exchange rate as an additional variable in equation (3) will 
result in more stable macroeconomic outcomes. According to a simulation exercise undertaken by Svensson (2000) the optimal values of the exchange rate coefficients are $h$ ${ }_{0}=-0.45$ and $\mathrm{h}_{1}=0.45$. Ball (1999) analysis suggests that macroeconomic instability will be reduced if $h_{0}=-0.37$ and $h_{1}=0.17$. In a recent study Ades (2002) has estimated a number of Taylor rules for emerging countries, and has concluded that the majority of them do pay some attention to the exchange rate when conducting monetary policy. Although analyses on these issues still are at a preliminary stage, it is clear that not all policy reactions to exchange rate development need to be sub-optimal, nor should be labeled as "fear of floating."

The preceding discussion has been undertaken in terms of "non sterilized" intervention, where the authorities alter the course of monetary policy in response to developments in the exchange rate front. A somewhat different question - and possibly a more important one from a policy perspective - is whether it is optimal for the authorities to engage in "sterilized intervention." Goldfajn and Silveira (2002) have recently addressed this issue. The point of departure of their analysis is the simple proposition that in the absence of externalities it is difficult to justify government interventions. They then build a general equilibrium model where debtors and creditors have different views of the world. More specifically, debtors are more pessimistic than creditors. In this world with heterogeneous beliefs, there are "congestion" effects and the private sector will tend to under hedge its foreign currency exposure. The authors show that in this case - and under the assumption of an overly pessimistic foreign sector - government intervention to smooth exchange rate risk may, indeed, be Pareto improving. Whether this type of results can be generalized will require additional research.

\section{Concluding Remarks}

The recurrence of currency crises during the last few years has prompted analysts and academics to reconsider the traditional wisdom regarding exchange rate policy. An important development has been the so-called "two-corners" solution, according to which emerging nations should avoid intermediate exchange rate regimes. They should either

22 In this formulation an increase in e denotes a real exchange rate appreciation. 
opt for a floating exchange rate or for a hard peg - a currency boards or strict dollarization.

For many years Argentina was considered to be the greatest example of the merits of super-fixed exchange rate regimes. The abandonment of the currency board in early 2002, and the massive collapse of the Argentine economy, have opened a host of questions regarding the selection of exchange rate regimes in developing countries. While for some authors this episode reflected the fact that super-fixed regimes were highly inflexible and inhibited the adjustment process, for others it was an illustration that "true" super-fixity - that is dollarization - was the only feasible exchange rate regime for the emerging economies. Recent discussions have also dealt with the feasibility of having genuine floating rates in countries with underdeveloped capital markets. In this paper I have analyzed some of the most important issues that have been at the center of the exchange rate debate. I have reviewed the experience with strict dollarization, and I have discussed problems related with "fear of floating." I argue that economic performance under dollarization has been mixed: while inflation has been lower in dollarized countries than in countries with a currency of their own, growth has been significantly lower. Proponents of the "fear of floating" view argue that emerging countries cannot have a true floating regime: they systematically intervene in the foreign exchange market, creating a highly unstable economic environment. I argue that in many cases it is optimal for these countries to react to exchange rate developments. It is not "fear of floating," it is "optimal floatation." 
TABLE 1

Matching Estimators:

Inflation, GDP per Capita Growth and Volatility*

\begin{tabular}{|c|c|c|c|c|}
\hline & $\begin{array}{c}\text { Number of } \\
\text { Control } \\
\text { Countries } \\
\end{array}$ & $\begin{array}{c}\text { Number of Control } \\
\text { Observations }\end{array}$ & $\begin{array}{c}\text { Mean } \\
\text { Difference }\end{array}$ & $\begin{array}{c}\text { Median } \\
\text { Difference }\end{array}$ \\
\hline \multicolumn{5}{|c|}{ A. Inflation } \\
\hline M1R & 22 & 197 & $\begin{array}{l}-3.53 \\
(-5.68)\end{array}$ & $\begin{array}{l}-3.15 \\
(-4.00)\end{array}$ \\
\hline $\mathrm{M} 1 \mathrm{~N}$ & 28 & 197 & $\begin{array}{l}-3.39 \\
(-5.01)\end{array}$ & $\begin{array}{l}-1.92 \\
(-2.82)\end{array}$ \\
\hline M5R & 31 & 985 & $\begin{array}{c}-3.89 \\
(-9.03)\end{array}$ & $\begin{array}{l}-4.45 \\
(-9.89)\end{array}$ \\
\hline M5N & 53 & 985 & $\begin{array}{l}-5.68 \\
(-5.98)\end{array}$ & $\begin{array}{c}-4.42 \\
(-8.41)\end{array}$ \\
\hline \multicolumn{5}{|c|}{ B. GDP per capita growth } \\
\hline M1R & 29 & 386 & $\begin{array}{l}-0.28 \\
(-0.47)\end{array}$ & $\begin{array}{l}-1.05 \\
(-3.03)\end{array}$ \\
\hline $\mathrm{M} 1 \mathrm{~N}$ & 35 & 386 & $\begin{array}{l}-1.56 \\
(-2.78)\end{array}$ & $\begin{array}{c}-1.53 \\
(-3.88)\end{array}$ \\
\hline M5R & 40 & 1,930 & $\begin{array}{l}-1.12 \\
(-2.48)\end{array}$ & $\begin{array}{l}-1.01 \\
(-3.34)\end{array}$ \\
\hline M5N & 79 & 1,930 & $\begin{array}{c}-1.19 \\
(-2.78)\end{array}$ & $\begin{array}{l}-1.30 \\
(-2.71)\end{array}$ \\
\hline \multicolumn{5}{|c|}{ C.Volatility of Growth } \\
\hline M1R & 12 & 386 & $\begin{array}{c}0.86 \\
(0.63)\end{array}$ & $\begin{array}{c}0.42 \\
(0.24)\end{array}$ \\
\hline M1N & 16 & 386 & $\begin{array}{c}0.62 \\
(0.40)\end{array}$ & $\begin{array}{l}1.29 \\
(0.51)\end{array}$ \\
\hline M5R & 71 & 1930 & $\begin{array}{c}0.72 \\
(0.74)\end{array}$ & $\begin{array}{l}1.59 \\
(0.86)\end{array}$ \\
\hline M5N $\mathrm{N}^{\mathrm{a}}$ & - & - & - & - \\
\hline
\end{tabular}

*: M1R refers to one nearest neighbor, with replacement. M1N refers to one nearest neighbor, without replacement. M5R refers to five nearest neighbors, with replacement. M5N refers to five nearest neighbors, without replacement. Numbers in parentheses are t-statistics.

a: Not computed because the number of observations was too small.

Source: Edwards and Magendzo (2001). 


\section{BIBLIOGRAPHY}

Ades, A. (2002), "Taylor Rules in Emerging Markets," in Goldman Sachs Emerging Market Strategy, 02,12 (July)

Ball, L (1999), "Policy Rules for Open Economies," in J.B. Taylor (Ed) Monetary Policy Rules, U. of Chicago Press

Blundell, R., A and Costa Dias, M. (2000), "Evaluation Methods for Non-Experimental data," Fiscal Studies, 21, 427-468.

Bogetic, Z. (2000). "Official Dollarization: Current Experiences and Issues", Cato Journal; 20(2), 179-213.

Calvo, G. A. 1999. "Fixed vs. Flexible Exchange Rates. Preliminaries of a Turn-ofMillennium Rematch.” University of Maryland. Mimeo.

Calvo, G. A. and C. Reinhart 2002, "Fear of Floating," Quarterly Journal of Economics, 2002

Edwards, S. (1992) "Stabilization and Liberalization Policies for Economies in Transition," in C. Clague and G. Rauser (Eds) The Emergence of Market Economies in Eastern Europe, Blackwell

Edwards, S. (2001). "Dollarization: Myths and Realities”, Journal of Policy Modeling 23(3), 249-65.

Edwards, S. and A.C. Edwards (1991) Monetarism and Liberalization: The Chilean Experiment, University of Chicago Press.

Edwards, S. and E. Levy-Yeyati (2002). "Flexible Exchange Rates as Shock Absorbers: An Empirical Investigation," UCLA Working Paper

Edwards, S. and I. I. Magendzo (2002) “Dollarization, Inflation and Growth” ", NBER Working Paper, No 8671.

Edwards, S. and M. A. Savastano. 1999. "Exchange Rates in Emerging Economies: What Do We Know? What Do We Need to Know?” NBER Working Paper W7228.

Eichengreen, B. J, P. Masson, M. Savastano and S. Sharma. 1999. "Transition Strategies and Nominal Anchors on the Road to Greater Exchange-Rate Flexibility." Essays in International Finance, No. 213, Princeton University Press.

Engel, C. and A.K. Rose (2002), "Currency Unions and International Integration" Journal of Money Credit and Banking 
Fan, J. (1992). "Design-adaptive Nonparametric Regression (in Theory and Methods)" Journal of the American Statistical Association 87(420), 998-1004.

Fischer, S. (2001). "Exchange Rate Regimes: Is the Bipolar View Correct?", Journal of Economic Perspectives; 15(2), 3-24.

Frankel J. and Rose, A.K (2002), "An Estimate of the Effect of Common Currencies on Trade and Income," forthcoming, Quarterly Journal of Economics

Goldfajn I. and M. A. Silveira (2002) "Should Government Smooth Exchange Rate Risk?" Journal of Development Economics, Forthcoming

Hochreiter, E. K. Schmidt-hebbel and G. Winckler (2002), "Monetary Unions: European Lessosn, Latin American Prospects," Presented at the Vienna Conference on Currency unions.

Levy Yeyati, E. and F. Sturzenegger. 2000. "Classifying Exchange Rate Regimes: Deeds vs. Words". Working Paper 2, Universidad Torcuato Di Tella.

Lipton, D. and J. Sachs, (1990) "Creating a Market Economy in Eastern Europe," Brookings Papers on Economic Activity, 1, 75-147

Mussa M. (2002), Argentina: From Triumph to Tragedy, IIE, Washington D.C.

Obsfeld, M. and K. Rogoff (1995) “The Mirage of Fixed Exchange Rates," Journal of Economics Perspectives, Fall

Persson, T. (2001), "Currency unions and Trade: How Large is the Treatment Effect?" IIE, April.

Reinhart, C. (2000), "The Mirage of Floating Exchange Rates," American Economic Review, May

Reinhart, C. and K. Rogoff (2002), "The Modern History of Exchange Rate Arrangements: A Reinterpretation,” NBER WP 8963

Rosenbaum P.R. and D.B. Rubin (1983), "The Central Role of the Prpensity Score in Observational Studies for Causal Effects", Biometrika 70, 41-55.

Summers, L. H. 2000. "International Financial Crises: Causes, Prevention and Cures" American Economic Association, May

Svensson, L. (2000) “Open-economy Inflation Targeting," Journal of International Economics, February, 50, p. 117-153 
Taylor, J. (2001) "The Rules of Exchange Rates in Monetary Policy Rules," American Economic Review, May 